\title{
THE WINTER TRENDS IN AIR TEMPERATURE AND ATMOSPHERIC PRECIPITATION IN THE MOLDOVA REGION (ROMANIA)
}

\section{Ovidiu - Miron Machidon ${ }^{1}$}

Key words: temperature, precipitation, winter, Moldova, trends

\begin{abstract}
The study is a comparative analysis of the characteristics of air temperature and atmospheric precipitations in winter seasons from the WMO reference periods $(1961$ - 1990, 1981 - 2010) compared with last 7 years $(2010-$ 2016). There is a continuous increase of air temperature in winter, from $-2,0^{\circ} \mathrm{C}$ between $1961-1990$, to $-1,1^{\circ} \mathrm{C}$ between $2010-2016$, so a heating of $0,9^{\circ} \mathrm{C}$. In the last 7 years $(2010-2016)$ the average number of frosty nights (nights with minimum temperature of $\leq-10^{\circ} \mathrm{C}$ ) was reduced by $18 \%$ compared to the period 1961-1990 and by $3 \%$ compared to the period 1981-2010. In the same period $(2010-2016)$, the rainfall were higher in winter, respectively by 17\% than during 1961-1990 and by $22 \%$ than during 1981-2010. There is an increase of torrential character of precipitation, more pronounced in the southern region of Moldova.
\end{abstract}

\section{Introduction}

In the first decade of the 21st century, the territory of Moldavia has faced with unprecedented sequence of very warm periods and very moist and rainy periods, some of them surpassing the records of the entire period of meteorological observations. In respect of the pluviometric aspect, the year 2007 recorded a deficit, and as for the temperature, it was the warmest year in the last 50 years (Machidon, O., Budui, V, 2009). For whole territory of Romania, temperature variations and tendencies was studied (Ciulache \& Ionac, 1994; Iliescu, 1991, 1992, 1994). The National Meteorological Administration in Romania has recently conducted an assessment of the current climate in Romania, featuring the air temperature, mainly in terms of its territorial distribution and secondly regarding its time evolution (Climate of Romania, 2008). For the different parts of the Moldavia,

\footnotetext{
${ }^{1}$ Regional Meteorological Centre of Moldova, National Meteorological Administration of Romania: ovidiumachidon@yahoo.com
} 
different analyses of the air temperatures variations was made (Apăvăloaie at all, 1993; Apostol, 2004; Apostol \& Apăvăloaie, 2002; Mihăilă, 2006; Apostol \& Sfica, 2013).

The recent studies, which analyzed the surplus rainfall and/or its variation and the climate change in Romania, showed a slight downward trend of atmospheric precipitations in Moldova region from the period of $1961-2007$ (Busuioc at all, 2010), or an increasing trend if we take into account the period of $1945-2010$ (Machidon, 2011). Some other studies have analyzed the variations of precipitations from some areas in Moldova region (Dragotă, 2006; Tănase, 2010), or the impact of climatic teleconnections identified in the Northern Hemisphere on precipitations variability from Moldova territory (Sfica L, 2004).

\section{Methodology}

The paper is based primarily on the factual material represented by continually measured data of air temperature and atmospheric precipitations by the 8 weather stations located in Botoșani, Suceava, Iași, Piatra Neamț, Bacău, Vaslui, Bârlad and Galați (fig. 1), during the winter seasons in the 1961- 2016 period. The WMO reference periods (1961-1990; 1981-2010) compared with last 7 years , the statistical-mathematical processing of the climatic data and their graphical representation are the methods through which the corpus of data collected from the weather stations measurements has been developed. Furthermore, both methods were used in the graphical transposition of the results obtained by averaging the data from the eight weather stations. In order to establish a trend, we have used the method of moving averages, on a time series of 10 years, shifted with a year calculated by averaging the values recorded by those weather stations. The trend line has been drawn by using EXCEL.

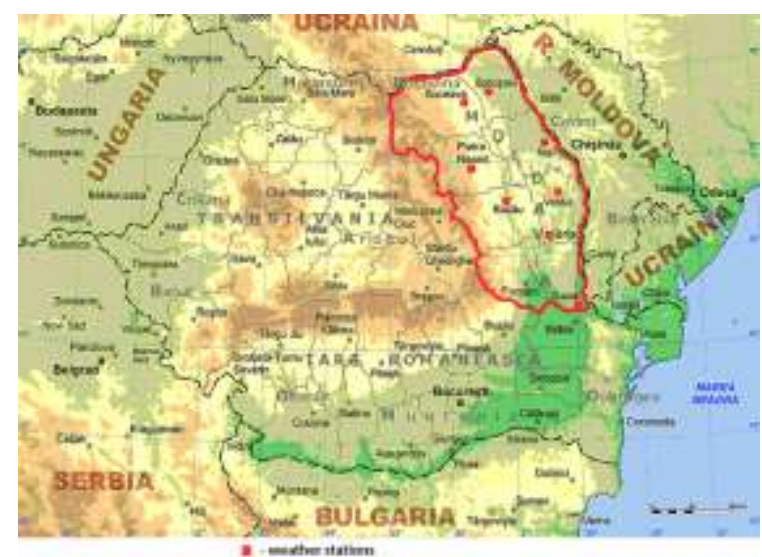

Fig. 1. Locations of weather stations in Moldova region (Romania) 


\section{Obtained results}

Air temperature. The air temperature is an important parameter to define and characterize the potential of climate, by its oscillations and its distribution is depending overall the appearance of the geographical landscape.

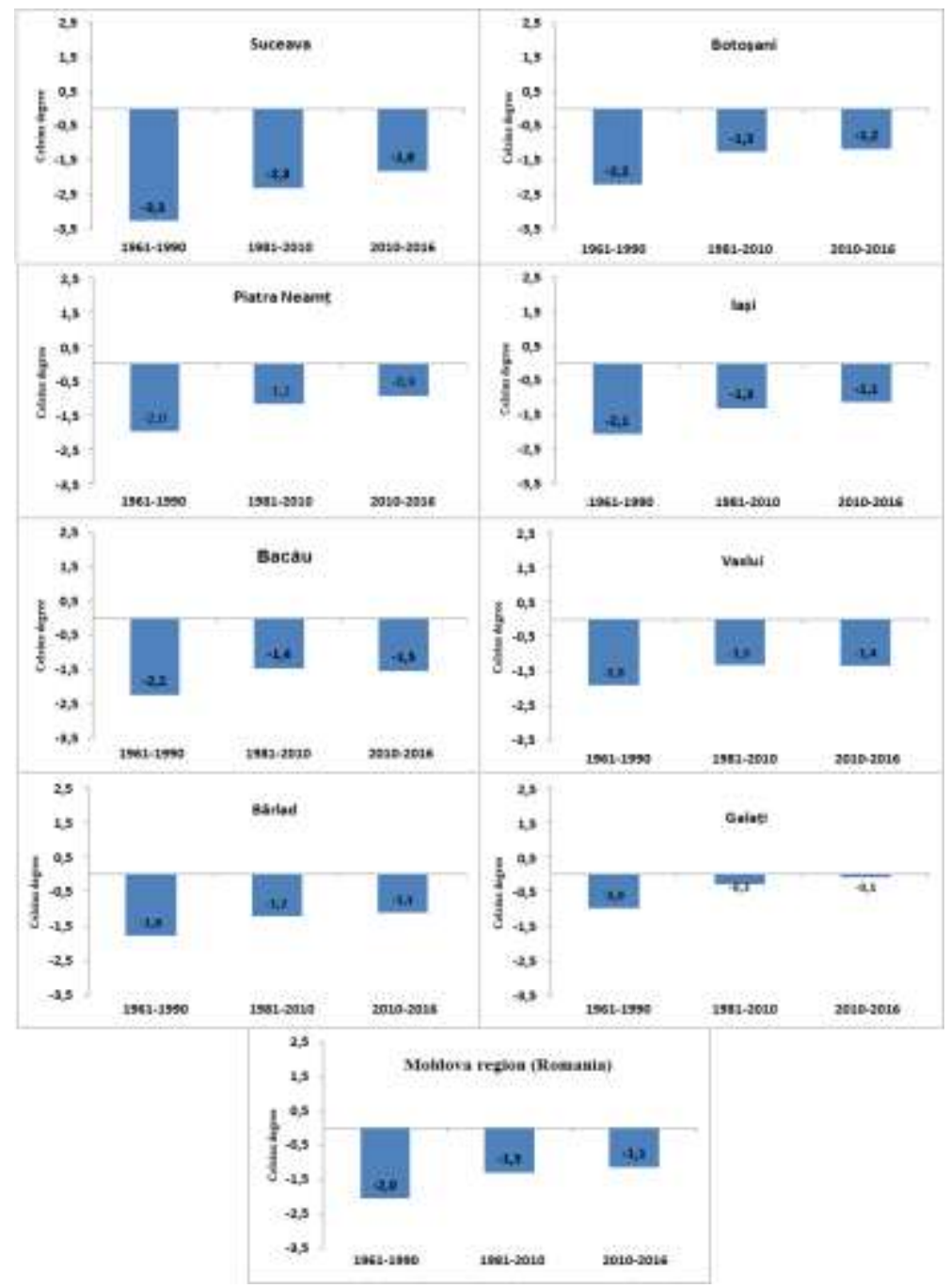

Fig. 2. Periodically mean air temperature in winter in Moldova region (Romania) from the periods of 1961 - 1990, $1981-2010$ and 2010-2016 
In the WMO reference periods compared with last 7 years, the mean air temperature recorded during the winter was increase, apparently from one period to another, most intense in the northern of Moldova. At the Suceava meteorological station was recorded in the period of $1981-2010$ an mean temperature by $-2,3^{\circ} \mathrm{C}$, with $1,0^{\circ} \mathrm{C}$ bigger than the mean temperature recorded in the $1961-1990$ period and with $0,5^{\circ} \mathrm{C}$ smaller than the mean temperature recorded in the $2010-2016$ period (fig. 2).

The lowest increase was registered in the central area of Moldova region. For the example, at Vaslui and Bârlad meteorological stations was recorded in the period of $1981-2010$ an mean temperature by $-1,3^{\circ} \mathrm{C}$ at Vaslui and $-1,2^{\circ} \mathrm{C}$ at Bârlad, both values being with $0,6^{\circ} \mathrm{C}$ bigger than mean temperature recorded in 1961 - 1990 period. An important notice is the fact that in the central part of Moldova, at two station (e.g. Vaslui and Bacău) was recorded an decrease of the mean air temperature in the period of $2010-2016$, compared with the period of $1981-2010$ (fig. 2).

Registering at long intervals without regularly, highs and lows temperature are primarily a result of atmospheric circulation conditions, and secondly of the influence of local geographical factors. The deepening winter cooling in the region of Moldova is favored not only by the advection of cold air masses but also their long time stagnation in this region.

It can readily observe that, the periodic evolution of mean air temperature during the winter seasons, throughout 10-year intervals in the 1961 to 2016 period, indicates a rising trend in Moldova region (Fig. 3).

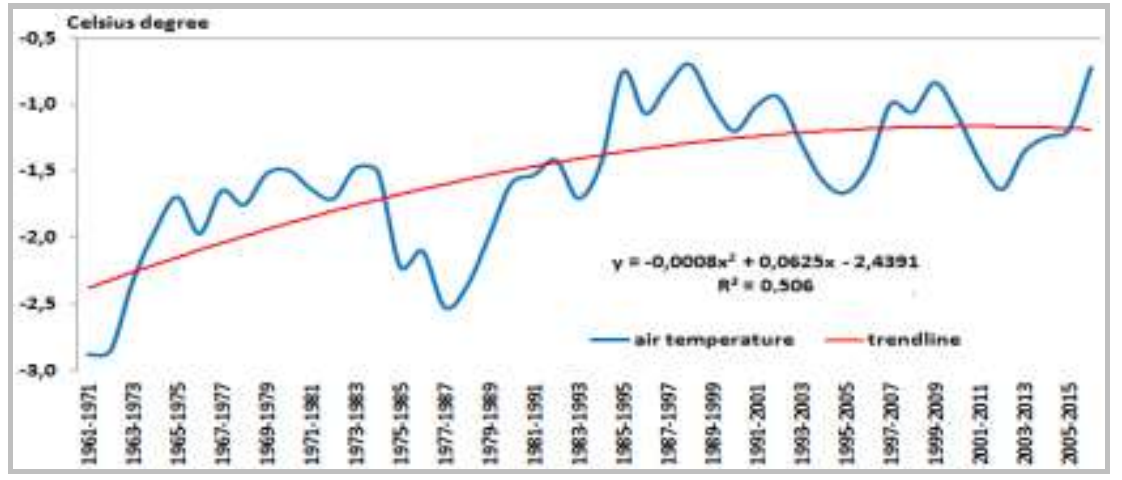

Fig. 3. The moving averages over a 10 -year time series, shifted successively with one year of the air temperature overall Moldova region (Romania) from the period of $1961-2016$

In Moldova region (Romania) the periodic evolution of the number of days with maximum air temperature $\leq 0^{\circ} \mathrm{C}$, considered the winter days by the romanian climatology, throughout the WMO reference periods and last seven years, indicates 
a decreasing trend (Fig 4). In the figures 5, number of nights with minimum air temperature $\leq-10^{\circ} \mathrm{C}$ (frosty nights considered) show the same decreasing trend in the analyzed region.

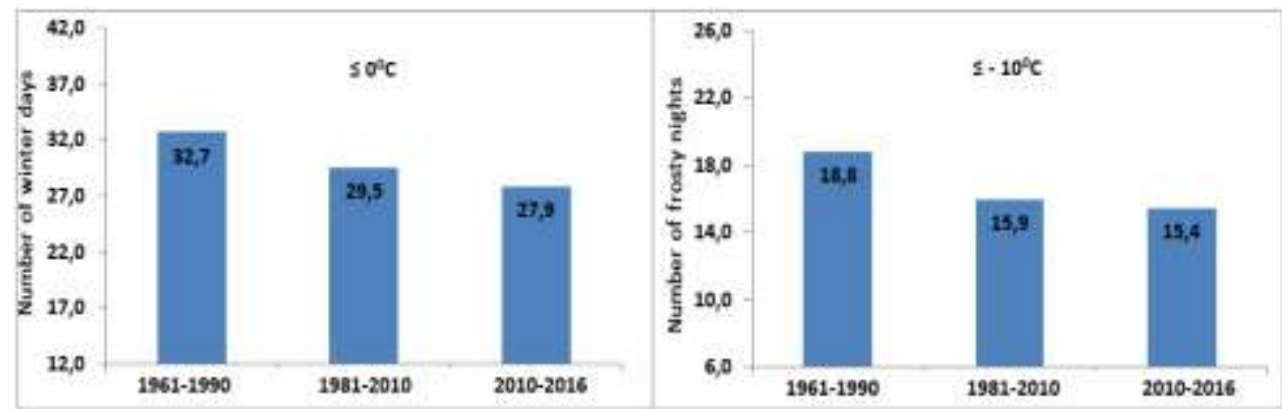

Fig. 4. Periodically mean values of the number of winter days with minimum air temperature $\leq 0^{0} \mathrm{C}$ overall Moldova region
Fig. 5. Periodically mean values of the number of frosty nights with minimum air temperature $\leq-10^{\circ} \mathrm{C}$ overall Moldova region

Atmospheric precipitations. The practical importance of atmospheric precipitation is daily observed in economic sectors such as agriculture, forestry, construction, transport, tourism, spatial planning and organizing etc, especially when is recorded large amounts of precipitations in medium or a short time, or not coming at all, or in very small amounts over long periods.

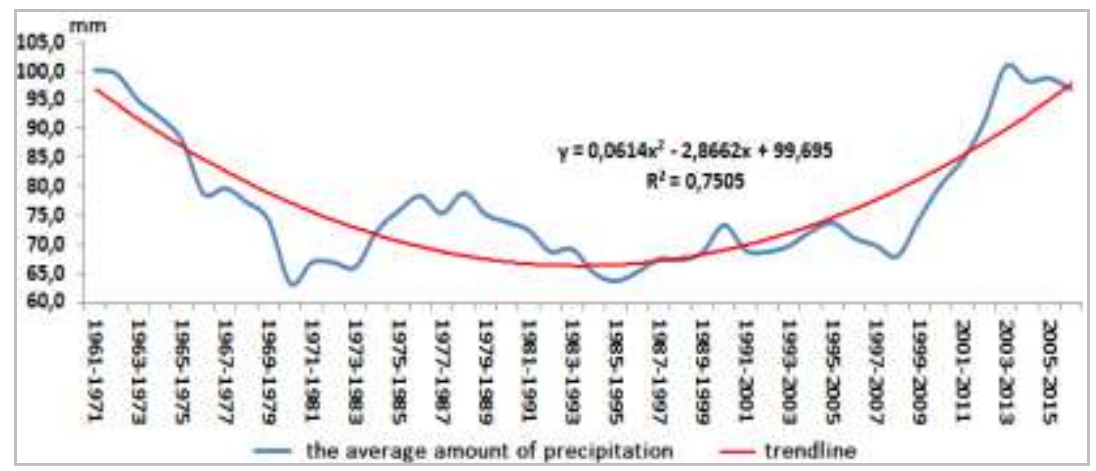

Fig. 6. The moving averages over a 10 -year time series, shifted successively with one year of the average precipitation amounts in the winter overall Moldavian territory $(1961-2016)$

Long-term trends, in 1961-2016 period, of the evolution in the atmospheric precipitation amounts, show the rising trend in the last 15 years in Moldova region 
(Fig. 6). One can observe that the number of days with a precipitation of $\geq 0.1 \mathrm{~mm}$ (Fig. 7) shows an continues downward trend overall Moldova territory.

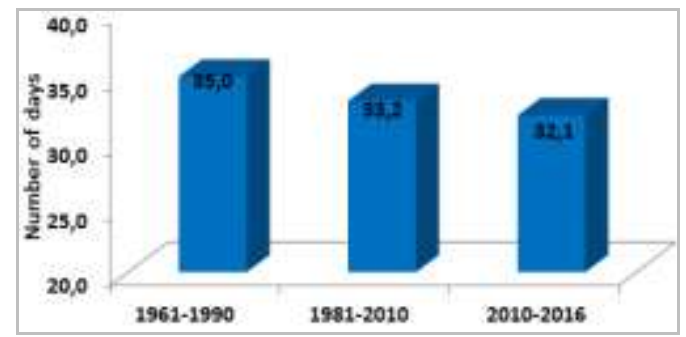

Fig. 7. Periodically number of days with a precipitation of $\geq 0.1$ $\mathrm{mm}$ per day in the winter overall Moldova region (Romania) from the periods of $1961-1990,1981-2010$ and 2010-2016

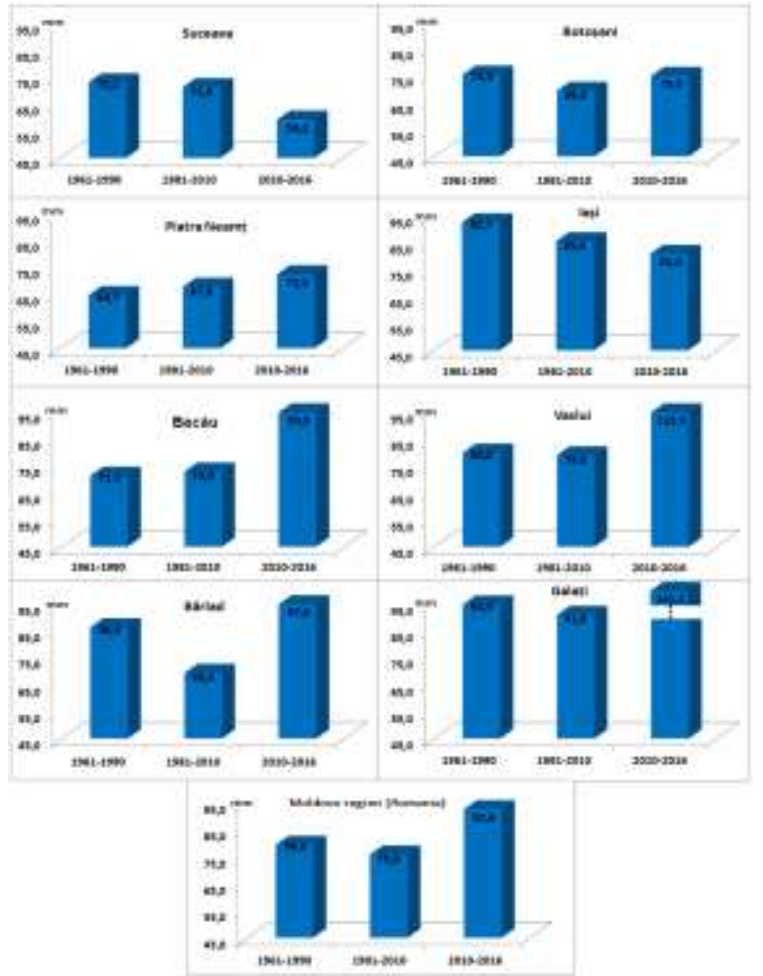

Fig. 8. Periodically mean amounts of the atmospheric precipitation quantities in the winter overall Moldova region (Romania) from the periods of $1961-1990,1981-2010$ and 2010-2016 
One can readily observe that, the periodic evolution of mean values of precipitation quantities in winter season, throughout the WMO reference periods compared with last 7 years in the 1961 to 2016 period, indicates a rising trend analyzed by 5 of the 8 weather stations and a decreasing trend at two weather stations (fig. 8).

Calculations based on long sets of observations (1961 - 2016) throughout the WMO reference periods compared with last 7 years, have indicated an increasing movement of the value of the mean number of days with a precipitation of $\geq 20$ $\mathrm{mm}$ and $\geq 30 \mathrm{~mm}$ in the winter season (fig. 9).

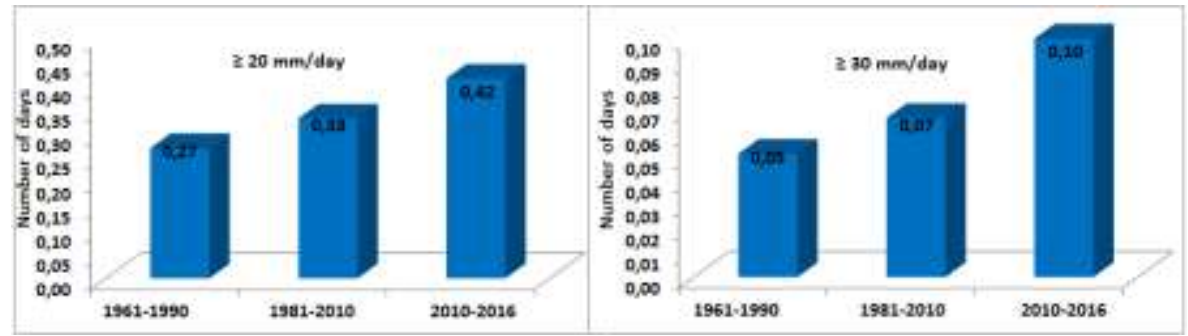

Fig. 9. Periodically number of days with precipitation $\geq 20 \mathrm{~mm}$ and $\geq 30 \mathrm{~mm}$ per day in the winter season overall Moldova region (Romania)

The mean number of days with precipitation $>30 \mathrm{~mm}$ indicates a shift of the deviations towards the register of values above average, this being an argument in favour of increasing of the torrential character of precipitation in winter in the last 7 years in season in Moldova region (Romania), more pronounced in the southern part of the region (fig. 10).

The main forms of atmospheric precipitation are liquid and solid. First form of precipitation dominates in the warm season and the second in cold season. Increasing of air temperature is reflected in the evolution of the precipitation forms during the winter, within the meaning of increased proportion of the number of days with liquid precipitation from the total number of days with precipitation (fig. $11)$. 


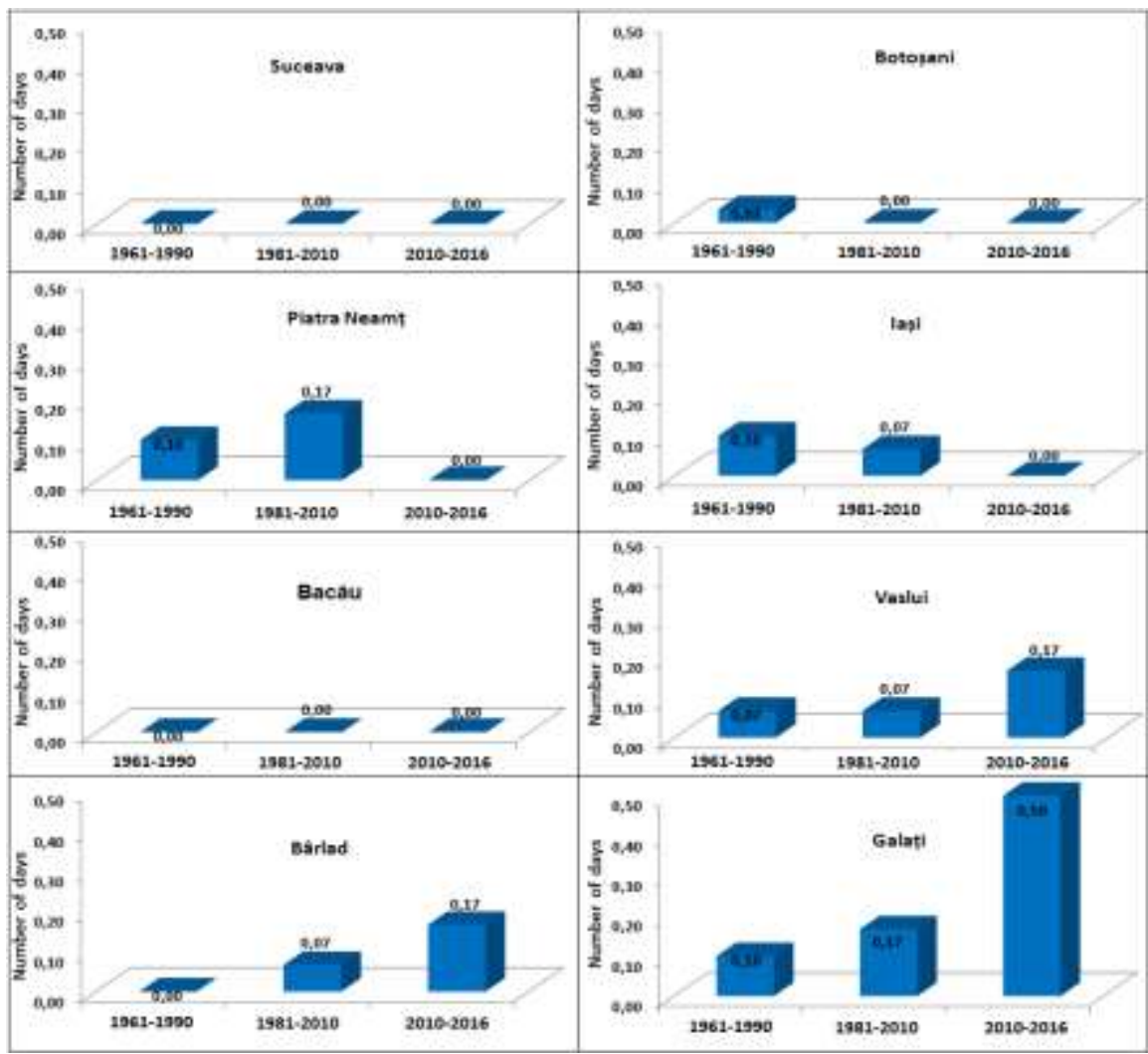

Fig. 10. Periodically number of days with precipitation $\geq 30 \mathrm{~mm}$ per day in winter at the weather stations overall Moldova region (Romania) from the periods of $1961-1990,1981-2010$ and 2010-2016

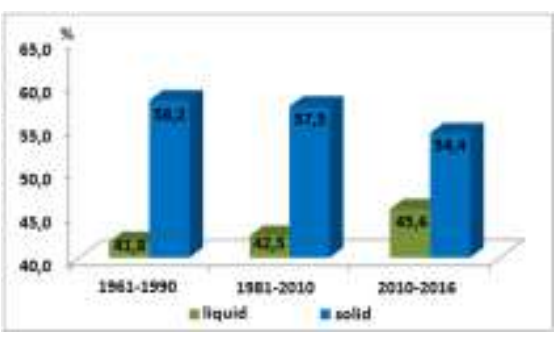

Fig. 11. Periodically proportion of mean number of days with liquid and solid precipitation from total number of days with atmospheric precipitation in the winter overall Moldova region (Romania) from the periods of 1961 - 1990, $1981-2010$ and 2010-2016 
Generally snowfall are generating snow cover at the surface. In Moldova region (Romania) the snow cover is increasing from october until february and decrease gradually by melting to the totally disappearence at latest in April, exceptionally in May (Mihaila, 2006). The results shows that the number of days with solid precipitation has periodically decreased in winter overall Moldova region (fig. 12). At the same time it is noted that the mean thickness of snow cover has excessively increased in the last 7 years (fig. 13). That indicates the fact that the quantities of water in the days with solid precipitation has increased in the last 7 years.

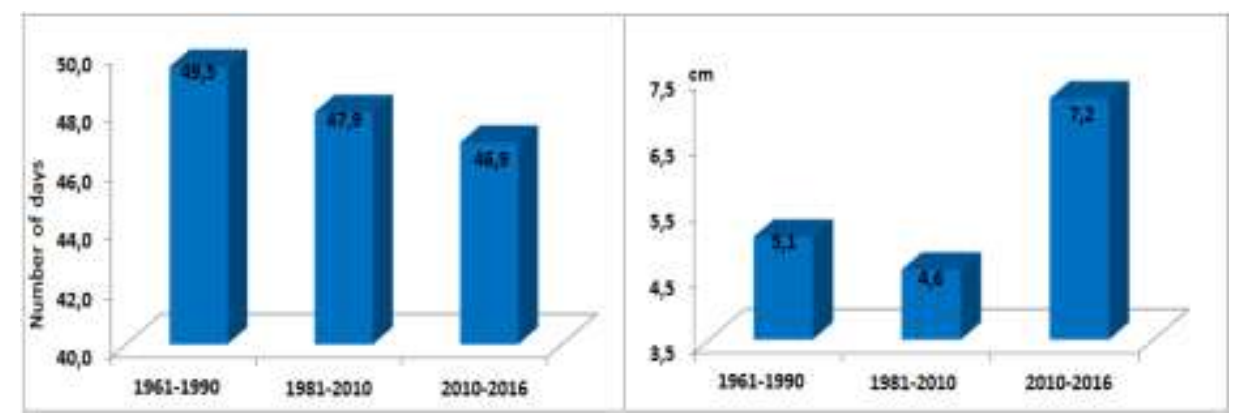

Fig. 12. Periodically mean number of days with solid precipitation overall Moldova region (1961 - 2016)

Fig. 13. Periodically mean values of snow thickness overall Moldova region $(1961-2016)$

\section{Conclusions}

Calculations based on long sets of observations (1961-2016) have indicated that the mean air temperature show an increasing trend in winter. In the winters of the last 7 years $(2010-2016)$ the mean air temperature was with $0,9^{\circ} \mathrm{C}$ higher than 1961-1990 period and with $0,2^{\circ} \mathrm{C}$ higher than $1981-2010$ period. The increasing trend was most intense in the northern part of Moldova region (Romania). The lowest increase was registered in central and southern parts of the analyzed region.

The evolution of the thermal regime is inversely reflected in the annual regime of winter days and frosty nights. In the period of $2010-2016$ the mean number of frosty nights decreased in winter with $18 \%$ against the $1961-1990$ period and with $3 \%$ against the 1981 - 2010 period. The same downward trend was noticed on winter days (reduction by $15 \%$ against the $1961-1990$ period and by $5 \%$ against the $1981-2010$ period).

As a consequences of temperature growing there is:

- an increased proportion of the number of days with liquid precipitation from total number of days with precipitation, which reached an average of $45,6 \%$ 
in the last 7 years, beeing with $3,8 \%$ higher than $1961-1990$ period and 3,1\% than 1981 - 2010 period;

- reducing the mean number of days with snow cover from 49,5 days in the period of 1961 - 1990 to 47,9 days in the period of $1981-2010$ and at 46,9 days in the last 7 years $(2010-2016)$.

In the last 7 years (2010-2016) the mean quantities of atmospheric precipitations has became higher than that two WMO references periods (1961 1990 and 19812010 ), respectively with $17 \%$ against the $1961-1990$ period and $22 \%$ against the $1981-2010$ period.

Increasing the mean quantities of water from atmospheric precipitations, increasing the mean number of days with large quantities of water in 24 hours and increasing the mean thickness of snow cover are clear arguments that the torrential character of atmospheric precipitations was intensified in the winter seasons of the last 7 years $(2010-2016)$ in Moldova region (Romania).

\section{References}

Apăvăloae, M., Apostol, L., Pîrvulescu, I. (1993), Analiza ciclurilor multianuale ale variațiilor de temperatură în Subcarpații Moldovei, "Geogr. Timisensis", vol. II, pg. 56-67, Univ. Timişoara.

Apostol, L., Apăvăloae, M. (2002), Temperaturile medii multianuale în Subcarpații Moldovei, Lucr. Staţ. „Stejarul”, ser. Geogr., vol. 10, pg. 5-16, Piatra Neamţ.

Apostol, L. (2004). Clima Subcarpaților Moldovei, Editura Univ. Suceava, ISBN 9739408-81-8, Suceava.

Apostol, L., Sfică, L. (2013). Thermal diferentiations induced by the Carpathian mountains on the Romanian territory, Carpathian Journal of Earth and Environmental Sciences, vol. 8, nr. 2, ISSN Online: 1844 - 489X.

Busuioc, Aristița, Caian, Mihaela, Cheval, S., Bojariu, Roxana, Boroneanț, Constanța, Baciu, Mădălina \& Dumitrescu, A. (2010), Variabilatea și schimbarea climei în România, Editura Pro Universitaria, ISBN 978-973-129-549-7, București;

Ciulache, S., Ionac, Nicoleta (1994), General evolution trend of the air temperature in Romania, Anal. Univ. Bucureşti, ser. Geogr., an XLII.

Dragotă, Carmen (2006), Precipitațiile excedentare in România, Ed. Academiei Romane, ISBN 973-27-1435-2, București;

Iliescu, Maria Colette (1991), Variaţiile seculare a temperaturilor medii ale aerului pe teritoriul României, R.R.G., t.35, Edit. Academiei, Bucureşti.

Iliescu, Maria Colette (1992), Tendințe climatice pe teritoriul României, SCG, t. XXXIX, Edit. Academiei, Bucureşti.

Iliescu, Maria Colette (1994), Tendința variației pe timp îndelungat a temperaturii aerului pe teritoriul României, RRG, t. 38, Edit. Academiei, Bucureşti.

Machidon, O., Budui, V. (2009), Caracteristici agrometeorologice ale anului agricol 2006-2007 în bazinul hidrografic Bârlad, Analele Univ. „Ştefan cel Mare” Suceava, s. Geografie, t. XVIII; 
Machidon, O. \& Machidon, Dana (2011), Study of the evolution of atmospheric precipitation in Moldavia region (Romania) over the last 65 years, Annals of DAAAM for 2011 \& Proceedings of 22nd International DAAAM Symposium, ISBN 978-3-901509-83-4, ISSN 1726-9679, pp 1523-1524, Editor Branko Katalinic, Published by DAAAM International, Vienna, Austria;

Machidon, O., Apostol, L., Buruiană, D, Machidon, Dana, (2012), Study of the Evolution of Air Temperature in Moldavia Region (Romania) Over the Last 65 Years, Annals of DAAAM for 2012 \& Proceedings of the 23rd International DAAAM Symposium, ISBN 978-3-901509-91-9, ISSN 2304-1382, pp 0689 - 0692, Editor B[ranko] Katalinic, Published by DAAAM International, Vienna, Austria;

Mihăilă, D. (2006). Câmpia Moldovei - studiu climatic, Ed. Suceava University, ISBN 973-666-219-5, Suceava.

Sfică, L., (2004), L'impact des téléconnexions climatiques dans la variabilité des quantités de précipitations dans la région de la Moldavie, Analele Universității "Ovidius" seria Geografie, nr. 2, vol. I, 2004.

Tănase, I. (2010), Clima Podişului Sucevei - fenomene de risc, implicaţii asupra dezvoltării durabile, Teza de doctorat, Univ. Stefan cel Mare, Suceava;

*** (2008), Clima României, Ed. Academiei Romane, ISBN 978-973-27-1674-8, Administrația Națională de Meteorologie din România, București;

*** (1961-2016), Meteorological Tables TM1-1M, from the archive of Regional Meteorological Centre of Moldova (Romania), Iași 